Atanassova, T. (2021). Management of the business enterprise and its integrated development. Management as a science of complex development. Collection of Scientific Articles. European Scientific e-Journal, 6 (12), 7-18. Hlučín-Bobrovníky: “Anisiia Tomanek” OSVĆ.

Атанасова, Т. (2021). Management of the business enterprise and its integrated development. Management as a science of complex development. Collection of Scientific Articles. European Scientific e-Journal, 6 (12), 7-18. Hlučín-Bobrovníky: “Anisiia Tomanek” OSVČ.

DOI: $10.47451 / \operatorname{man} 2021-04-002$

EOI: $10.11244 / \operatorname{man} 2021-04-002$

The paper is published in Crossref, Internet Archive, Google Scholar, Academic Resource Index ResearchBib, JGate, ISI, CiteFactor, ICI, eLibrary databases.

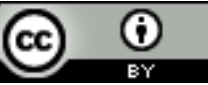

Todorka Atanassova

Professor, PhD in Economics

Department of Management

Faculty of Economics

Trakia University

Stara Zagora, Bulgaria

E-mail: tatanassova@abv.bg

\title{
Management of the business enterprise and its integrated development
}

\section{Abstract:}

The business enterprise is an object of management because it is being built and operates under the rules and norms established in the legislation of each country. The business enterprise can be also taken up as a subject of economy. The aim of the development is to analyze the peculiarities of the business enterprise, which is an open system made up of system-forming elements implying its integrated development. The methodical instruments used are based on several complementary approaches: a systematic approach and systematic analysis; a structural approach; a logical approach and a synergetic approach. Based on the principles of the systematic approach, we accept that the business enterprise is an 'input-output system'. the 'business enterprise' system are: production (business), financial and economic, juridical (legal) and social. The synergy between the constituent elements of its internal environment implies not only its integrity, but it is a major prerequisite for its successful integration into the external environment conditions.

Keywords:

business enterprise, system, subsystem, management, object and subject, development.

Тодорка Атанасова

Професор, А-р по икономика Катедра „Мениджмънт“

Стопански факултет

Тракийски университет

Стара Загора, България 
E-mail: tatanassova@abv.bg

\section{Управление на стопанското преАприятие и неговото интегрирано развитие}

Резгоме:

Стопанското предприятие е обект на управлението, защото се изгражда и функционира съгласно правилата и нормите, установени в законодателството на всяка държава. То може Аа бъде възприето и като субект на икономиката. Целта на разработката е да се анализират особеностите на бизнес преАприятието, което е отворена система, съставена от системообразуващи елементи, предполагащи неговото интегрирано развитие. Използваните методически инструменти се основават на няколко Аопъ $А$ ващи се подхода: систематичен подхоА и систематичен анаАиз; структурен подХоА; Аогичен поАХоА и синергичен подход. Въз основа на принципите на системния подход, ние приемаме, че стопанското предприятие е „входно-изходна система“. Съставните елементи на вътрешната среда на системата „стопанско предприятие“ са: производствена (бизнес), финансово-икономическа, юридическа (правна) и социална. Синергията межАу съставните елементи на вътрешната му среда преАполага не само нейната цялост, но е и основна предпоставка за успешното й интегриране в условията на външната среда.

Ключови думи:

бизнес предприятие, система, подсистема, управление, обект и предмет, развитие.

\section{Introduction}

A business enterprise is a 'generally recognized phenomenon' to which expectations of employment of the active working population, income, payment of taxes, etc. have been addressed. This role, which is given to the undertaking of activities, requires a profound knowledge of its immanent essence as a condition for its successful management and institutional treatment (Stankov et al., 1997; Stankov, 2009).

The business enterprise is an object of management because it is being built and operates under the rules and norms established in the legislation of each country (Atanassova, 2012; Atanassova, 2016). The economic activity carried out in the enterprise is the result of the selection of ruling circles and is subordinated to national and European legislation. Changes in regulatory provisions for businesses create prerequisites for stimulating the development of the enterprise but they may also limit it. As an object of management it can be considered in a structural and functional aspect. In the first aspect, it is manifested as a microsystem composed of elements and in the second one, it is interconnected with the external macro environment through its input and output. 
The business enterprise can be also taken up as a subject of economy. The basis for this understanding is that it is a major structural unit in the economy of each state. The enterprise as a subject in the national economy is distinguished by legal, economic, organizational and management and social autonomy. Its legal autonomy is due to the possibility of statutory provisions among which to choose a legal status, thus implementing the proprietary rights and obligations being enjoyed by the owners. The economic autonomy of the enterprise is associated with creation of own property and revenue and expenditure policy. Organizational and management autonomy is based on building an organizational structure that determines the way of making management decisions. Social autonomy implies a free hire of manpower, formation of rules for organization and payment of labor, etc.

The aim of the development is to analyze the peculiarities of the business enterprise, which is an open system made up of system-forming elements implying its integrated development.

To achieve the set goal, the following tasks are solved:

- The systemic nature of the business enterprise is clarified;

- The input-output character of the business enterprise is revealed;

- The immanent nature of subsystems that build the internal environment of the business enterprise is clarified;

- The synergy between the subsystems building the enterprise and their role for its management and integrated development is revealed.

The methodical instruments used are based on several complementary approaches:

1) a systematic approach and systematic analysis helping to consider the business enterprise as a complex system composed of elements found in interrelation with each other and the external environment;

2) a structural approach based on which the enterprise is decomposed in subsystems as separate elements of the internal system environment;

3) a logical approach that helps the analysis of the enterprise to be performed in accordance with the principles of identity and reasonableness.

4) The synergetic approach emphasizes the interaction of the elements of the 'business enterprise' system, which work out its internal structure (Bushev, 1992). Only systems that meet the condition of being open to the external environment are the object of synergetics research. By analogy with Ansoff, we use the synergistic approach to highlight the effect of the joint action of 
the elements of the system, where the final effect is the sum of their interaction (Ansoff, 1965).

The two-aspect consideration of the business enterprise as an object of management and a subject of the national economy is also a priori associated with its systemic essence as a prerequisite for its integrative development. By the 'integrated development' we understand a coordinated management of an enterprise that links the elements of its internal environment (its composite subsystems) into a single whole in order to adapt to the requirements of the external environment (Atanassova, 2002).

A number of leading authors have research and analysis on this topic, of which in the foreign literature these are: Hicks, Steffen, Born, Lin, Polenske, Albino, Nicolt, Petruzzelli, Yazan, Kohlas, Waldburger, Woehe et al. In Bulgarian literature, they have research on the subject: Kiranchev, Stankov and other.

\section{The business enterprise - 'input-output system', constituent parts}

Based on the principles of the systematic approach, we accept that the business enterprise is an 'input-output system', which is in a continuous relationship with the surrounding external environment. For the implementation of an economic activity, the enterprise buys raw materials, supplies, etc., delivered by the external environment. The realized output is the flow that goes out of the business enterprise.

According to professor Hicks, the term 'input' means what is 'bought for the enterprise', while what is 'sold' is the output and is defined as 'output'. Incoming resources form the costs of the enterprise, and the sold products/services its revenues. Therefore, the sum of the monetary values of the incoming resources is the sum of the total costs for a certain period (month, year), and the monetary value of the production (performed services) is its total income (Hicks, 1946). In this regard, based on the principles of identity and reasonableness of the logical approach, we accept that the material and value flow of the incoming resources in the enterprise is its 'input' and the one that goes out is its 'output'.

Similar opinions on this issue have a number of authors - Steffen, Born, Lin, Polenske, Albino, Nicolt, Petruzzelli, Yazan, Stankov, Kiranchev, who also view the enterprise as an 'input-output' system (Albinoet al., 2011; Albino \& Koehtz, 2004; Kiranchev, 2011; Lin \& Polenske, 1998; Stankov, 1997; Stankov et al., 1997; Steffen, 1987).

Accepting the understanding of these authors and based on a systematic approach, we assume that each stem is made up of elements, also called 
'subsystems'. Internal integrative connections are created between these elements, which build the integrity of the system. The constituent parts make up its internal environment. Separate subsystems communicate with the external environment through the input and output of the model. They must be developed in such a way as to ensure adaptation of the enterprise to the requirements of the external environment. This statement also applies to the business enterprise. The essence of the constituent elements (subsystems) of the enterprise is dictated by their role, which they have for its economic viability and integrative development.

Kohlas and Waldburger define the enterprise as a living system that grows, changes and integrates. According to them, it is made up of two elements subsystems. The first one they designate as a 'production cost subsystem' and the second one as a 'revenue subsystem'. This understanding derives from the costincome, respectively input-output nature of the enterprise (Kolhlus \& Waldburger, 1978).

Steffen and Born believe that there are three subsystems that make up the internal environment of the enterprise: biological and technical, economic and legal. They express their opinion that the three ones are mutually complementary and thus they allow the enterprise to integrate to the external environment (Steffen, 1987).

Stankov, based on the views of Steffen, Born and others, believes that the internal environment of the enterprise is a set of four subsystems, which means the concepts of production, economic, legal (regulatory), labor subsystem (Stankov, 2009; Steffen, 1987). The first, according to the author, is made up of a technical and technological part interconnected with the labor subsystem. The economic subsystem reflects the revenue and expenditure processes, and the legal one - the legal status of the enterprise. The last - the labor subsystem, includes staff with their qualifications and motivation and the author points out that all these characteristics of human capital taken together must correspond to the technique and technology to achieve the desired production result in the enterprise (Stankov, 2009).

By taking the opinion of the above-mentioned authors, based on the principles of the structural approach and of our own empirical research, we can specify that the elements (subsystems) which make up the 'business enterprise' system is production (business), financial and economic, juridical (legal) and social (Fig.1). This leads us to the analysis of the immanent essence of each composed element of the internal environment of the enterprise (Atanassova, 2002; Atanassova, 2012; Atanassova, 2016). 
The production (business) subsystem is a totality of production factors (assets) held and used by the enterprise, such as land, buildings, installation, equipment with the corresponding production capacity. These assets form the technological frameworks within which production processes are carried out and output is obtained. Based on them, the quantity and quality of the manufactured products and/or rendered services are determined, and hence the expected production results. On the one hand, the goods produced and/or the offered services satisfy societal needs and meet market demand. This requires that the choice of products should be to a significant extent in line with the market. On the other hand, the scope of production and its quality are a function of the size and technological capacity of the production factors available in the enterprise. The management of the enterprise must create conditions for maximising the use of the available production factors with their production potential. Otherwise, the production factors represent for the system as a whole expenditure or input made, without the corresponding revenue or output available. On the basis of the manufactured products, a production specialization and the enterprise's membership in a particular economic sector and sub-sector (heavy and light industry, agriculture, etc.) is determined.

The financial and economic subsystem of the enterprise reflects the value (monetary) dimensions of the available production factors (assets), which are created for the implementation of economic activity and technological basis of the production subsystem. In addition, this subsystem measures and accounts for the extent of production costs and the value of the output/services realized by the enterprise. The former are a reflection of the input, and the latter ones form the output of the system for a certain period of its activity. The economic efficiency of production is determined by the ratio of the 'output' to the 'input', that is, it is identified what amount of costs are invested in the production of a unit of income.

The enterprise implements financial management through revenue and expenditure analysis, changes in market conjuncture, etc., exercises planning, organization, control and regulation functions. The value of the owned assets, their structure and origin is reflected in the balance sheet of the enterprise. When comparing and analyzing the amount of equity and involved capital in the liabilities of the balance sheet used to acquire individual types of assets in the enterprise (long-term and short-term), conclusions can be made about its financial stability and capital independence. From the size of available liabilities and expected receivables, company liquidity can be identified and measures for its stability can be taken. The amount of owned equity, reflecting the value of available production 
factors, predetermines to a certain extent the type of the legal subsystem of the business enterprise. Based on the value of assets and annual revenues, the scale of the business enterprise (micro, small, medium or large) is measured.

There is an integrative link between the production and financial \& economic subsystems. While the financial and economic subsystem being under the influence of the external environment (market) requires rapid changes in the structure of production costs (distinguished by certain dynamics), the production subsystem is characterized by conservativity. The latter is explained by the smaller opportunities for change due to the immobility of production factors such as land, buildings, facilities. Thus, for a long period, they determine the type and quantity of production and production specialization. A change in the needs of society, respectively market demand, however, requires the introduction of new production technology, developing new products and services. Therefore, in order to integrate into the requirements of the external (market) environment, the management of the production subsystem should be adapted to the dynamic nature of the economic subsystem, i.e., to change product specialization of the enterprise.

The legal subsystem expresses the legal and organizational status of the enterprise by which it is identified as a legal entity in the national economy. This subsystem applies statutory provisions in the particular undertaking. On its basis, the internal environment of the enterprise is built to carry out legitimate activity and creates prerequisites for its integrated development (Unternehmen II: Wahl der Rechtsform, 1980). Internal rules for management, management bodies and relations between them are created. The legal subsystem integrates the financial and economic and production subsystems to the external requirements that are imposed by the macrosystem through its institutions. Management decisions are subject to legal statutory regulations, i.e., the enterprise is identified as an object of management as well. The type of enterprise's legal subsystem determines the rights, obligations and responsibilities of its owners, financial risks and associated limited or unlimited responsibility of the owners. Its type determines financing opportunities, trust of financial institutions in lending, tax liabilities, etc (Woehe, 1993).

Social subsystem. Its characteristics is determined by the owners of the capital, entrepreneur, hired workers and employees. Each of them acquires specific rights and obligations to implement the enterprise's objectives. In their joint work, certain relationships arise and various economic activities occur.

A major place in the social subsystem of each business enterprise has the owner whose ownership is a part or all of the available production factors (tangible 
and intangible assets). His fundamental rights are connected with the possession, the injunction and the use of capital in the enterprise. The rights of possession and injunction are realized through his ability to invest his capital in this type of economic activity and to create a certain legal status of an enterprise. The owner seeks not only to preserve but also to increase his property, driven by his primordial economic interest in increasing his own capital. This results in the high interest of the owner for the efficient use of capital and the realization of maximum profit from the activity. The way of using the assets in the production subsystem is important, leading to an increase in the volume of production, which is a prerequisite for integrated development of the enterprise.

It is possible for the owner to manage his property or to delegate the rights to another person to manage the enterprise. His responsibility is different, and the type and amount of the received income differ. In some cases, the owner's responsibility is unlimited (e.g., in the sole trader's enterprise in Bulgaria) and the income he receives it is the realized annual profit, but the risk he bears is also high. In other cases, his liability is limited to the amount of capital contributed to the enterprise (as in a limited liability company or a joint stock company). In this case the income received is the dividends for the number of possessed stakes or shares. The situation is similar in the cooperative, where the owner, through the concluded lease agreement on the agricultural land, delegates his rights of possession and injunction. He realizes his right of use through the income he receives in the form of rent for the leased land.

The entrepreneur-manager is the most active figure in the social subsystem of the enterprise. According to the World Economics Dictionary, his main function is to deal with uncertainty in a dynamic and imperfect market environment in which profit is a return on risk inextricably linked to enterprise management (Bannock et al., 1992). His social destiny is most strongly linked to the economic objectives of the enterprise. He receives the result of the production activity - the entrepreneurial profit. As the owner and hired worker/employee receive their rightly income earlier than him, the risk to the entrepreneur is highest. He acquires a part of the rights of the owner to dispose of and manage his property (land, capital) for a certain period of time by being obliged to pay a certain rent or lease, and in other cases interest. Therefore, a part of the entrepreneur's income is channelled to cover costs (production, capital, etc.). This motivates him to make the most efficient use of available land, equipment, buildings, capital.

The hired worker/employee is the third figure in the social subsystem of the enterprise, to whom it is destined to perform only a labor function. In the hierarchy 
of functional relationships, he is subordinate to the owner and the entrepreneur. The remuneration he receives is in the form of a monthly salary, or it is income for the work and required qualifications.

The social subsystem is closely linked to the other three subsystems. The production and economic results in the enterprise determine the amount of income received for the three figures in the social subsystem of the enterprise.

\section{Discussion}

The presented topic does not provide an answer to all problem areas related to the management of the business enterprise. In this sense, for future research and analysis, emphasis can be placed on some of the following research topics:

- Businesses must strive to build their internal structure in order to be able to adapt to the changing external environment. Management must organize the internal capacity of the enterprise in a way that contributes to achieving results outside it. This is achieved when there is a good interaction between management and entrepreneurship.

- The development of the business enterprise in the 21 st century is unthinkable without the use of information technology. This fact modifies and expands the geographical boundaries of the business. This imposes the paradigm that the management of the enterprise goes beyond national borders and globalizes.

- In modern conditions, corporate governance must follow not only national but also global trends in the development of business technologies, training and qualification of specialists, product quality and more. Management is required to accept these facts as a reality, and not to look at them as an expected perspective in order to successfully develop and expand the business in accordance with global trends.

- The management is required to outline a clear mission, to provide conditions for the development of leadership qualities, the opportunity to realize personal contribution in the enterprise and society. The paradigm for management, which is socially engaged in the development of society, was adopted. The management of the enterprise is assigned a much higher responsibility than the traditional one. "This responsibility is 'absolute", says Peter Drucker in his book 'The Practice of Management' and "no management can be exempted from profit policy for the simple reason that otherwise it is a threat to the economic and social system of the country" (Drucker, 2006). 
Deepening the analysis in one or more of the mentioned problem areas can help in developing different scenarios for sustainable and integrative development of the business enterprise, even in conditions of uncertainty in the external environment.

\section{Conclusion}

The business enterprise is a built input-output system, which is in constant connection with its surrounding environment. The synergy between the constituent elements of its internal environment implies not only its integrity, but it is a major prerequisite for its successful integration into the external environment conditions.

The three socio-economic figures are an expression of the participation of the human factor with its functional qualities in the creation and development of the economic activity of the enterprise. Differentiation in their functions is conditioned by the different rights and obligations of each.

In order to implement the long-term integrated development of the 'business enterprise' system, a sustainable legal and regulatory and institutional environment is required, which stimulate its management to satisfy the interests of society.

\section{References:}

Albino, V., Nicolt, M. De, Petruzzelli, A., \& Yazan, D. (2011) Integrating Enterprise Input-Output Modelling with GIS Technology for Supply Chain Analysis. Retrieved March 10, 2021, from http://www.iioa.org

Albino, V. \& Koehtz, S. (2004) Enterprise input-output model for local sustainable development - the case of a tiles manufacturer in Italy. Resources, Conservation and Recycling, 41, 165-176.

Ansoff, I. (1965). Corporate Strategy: an analytic approach to business policy for growth and Expansion. New York, NY: McGraw-Hill.

Atanassova, T. (2002). Analysis and evaluation of legal organizational forms of agricultural enterprises - on the example of Stara Zagora region. Dissertation.

Atanassova, T. (2012). The business enterprise - object of management and subject of the economy. St Zagora: Iskra-MI.

Atanassova, T. (2016). Management of the enterprise. Stara Zagora: Thracian University.

Bannock, G., Baxter, R., \& Davis. E. (1992). World Dictionary of Economics, 1. Burgas: Delfinpres.

Bushev, M. (1992). Synergetics, chaos, order, self-organization. Sofia: "St. Kliment Ohridski” University. 
Drucker, P. (2006). The Practice of Management., HarperCollins e-books.

Hicks, R. (1946). Value and Capital: Inquiry into some Fundamental Principles of Economic Theory. 2nd Revised Ed. Oxford University Press.

Kiranchev, G. (2011). Invisible hands of cross-sectional relationships. Retrieved March 01, 2021, from http://krizata.blog.bg/biznes/2011/11/08

Kolhlus, J., Waldburger, H. (1978). Informatik fuer EDV -Benuetzer. Bern, Stuttgart.

Lenzen, M. \& Lundie, S. (2012). Constructing enterprise input-output tables - a case study of New Zealand dairy products. Journal of Economic Structures, 1, 6.

Lin, X. \& Polenske, K. (1998). Input-Output Modelling of Production Processes for Business Management. Structural Change and Economic Dynamics, 9, 205-226.

Stankov, V. (1997). Theoretische Thesen ueber Unternehmen in der Landwirtschaft und ihre Verwirkungen in der Agrarreform in Bulgarien. Privatisierungsprozess. Rechtsformen und Betriebsstrukturen in Agrarbereich der mittel- und osteneuropaeischen Laender, 93-103. Halle-Saale: IAMO.

Stankov, V. et al. (1997). Organization and management of the agricultural enterprise (Agromanagement). Sofia: PSSA.

Stankov, V. (2009). The enterprise and its management - modern characteristics of economy. Economic Thought, 1, 49.

Steffen, B. (1987). Betriebs- und Unternehmensfuehrung in der Landwirtschaft. Stuttgart: Verlag Ulmer.

Unternehmen II: Wahl der Rechtsform. (1980). Handwoerterbuch der Wirtschaftswissenschaft, 8, 71-80. Stuttgart und New York: Verlag Gustav Fischer.

Woehe, G. (1993). Einfuehrung in der Allgemeine Betribswirtschaftslehre. 18. Auflage. Muenchen: Verlag Vahlen. 


\section{Appendix}

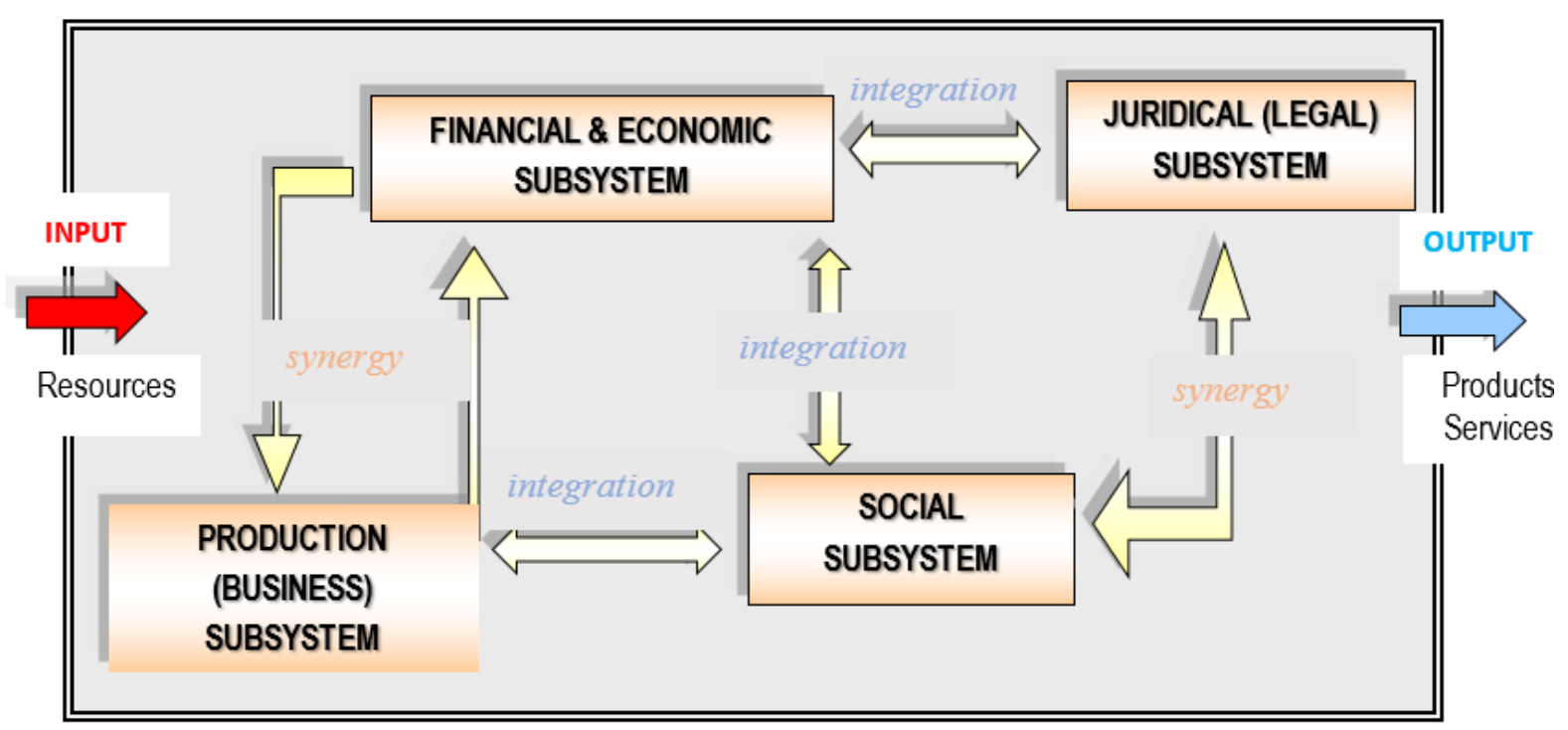

Figure 1. Subsystems which build the internal environment of a business enterprise (Atanassova, 2012; Atanassova, 2016) 